\title{
The Jesus of Paul: A contribution from the social sciences
}

\author{
Author: \\ Santiago Guijarro ${ }^{1,2}$ \\ Affiliations: \\ ${ }^{1}$ Faculty of Theology, \\ University of Pretoria, \\ South Africa \\ ${ }^{2}$ Faculty of Theology, \\ Pontificia de Salamanca \\ University, Spain \\ Note: \\ Prof. Dr Santiago Guijarro \\ is a research associate \\ of Prof. Dr Ernest van \\ Eck, Department of New \\ Testament Studies, Faculty \\ of Theology, University of \\ Pretoria, in collaboration \\ with their shared \\ participation in the Context \\ Group: A Project on the \\ Bible and its Cultural \\ Environment (USA)
}

Correspondence to:

Santiago Guijarro

email:

sguijarroop@upsa.es

Postal address:

Plaza del Concilio de Trento

4, 37001 Salamanca,

España 923261979

Dates:

Received: 28 May 2010

Accepted: 25 July 2010

Published: 07 June 2011

How to cite this article:

Guijarro, S., 2011

'The Jesus of Paul: A

contribution from the

social sciences', HTS

Teologiese Studies/

Theological Studies 67(1),

Art. \#862, 6 pages. DOI:

$10.4102 /$ hts.v67i1.862

(C) 2011. The Authors.

Licensee: OpenJournals Publishing. This work

is licensed under the

Creative Commons

Attribution License.
The letters of Paul speak more frequently of the resurrected and exalted Jesus than they do of the earthly Jesus. Nonetheless, this does not mean that the apostle and his addressees did not know the teachings and main events of Jesus' life. Their insistence as to the heavenly identity of Jesus is as likely to have been motivated by contextual factors which guided the development of the primitive Christological confessions which Paul received in the years after his conversion. This article will focus on two of these factors: the configuration of the Christian communities of the Diaspora as foreign cults in a context of religious plurality and the new revelatory experiences which triggered the formation of a binitarian faith.

Determining the relationship between Jesus and Paul is one of the fundamental tasks of those who, like Prof. Andries van Aarde, study the origins of Christianity and the beginnings of Christian theology. The basic question in this regard, at least as it has been formulated recently by David Wenham (1995), is whether Paul was a follower of Jesus or the founder of Christianity (see also Wedderburn [1989] and Barbaglio [2006]). In this brief article, I would like to consider one aspect of this general topic and to offer a few suggestions that might contribute to a better understanding of the peculiar vision of Jesus that we find in the letters of Paul. In them, in fact, the apostle moves from the incarnation to the death and resurrection, leaving in the shadows the activity and teaching of Jesus to which the gospels subsequently give so much importance.

This contrast raises some questions concerning the knowledge which Paul had of the Jesus tradition and the value he accorded to it: What did he know about Jesus? Did he know the traditions which the evangelists later collected? Why does he not refer to them in his letters more frequently? By contrast, why does he give so much importance to the death and resurrection of Jesus and to Jesus' divine condition?

\section{Jesus in the letters of Paul}

Detlev Häusser (2006) has recently studied the traditional substratum of Christological faith as it appears in the letters of Paul and has identified four traditions which together constitute the point of departure for Paul's reflection. The first of these is the confession of faith in 1 Corinthians 15:5-3, which locates the nucleus of the kerygma in the events of the death and resurrection of Jesus. The second is the confession of Romans 1:3-4, in which Jesus' human origin (according to the flesh), bound to the lineage of David, is contrasted with his divine origin (according to the Spirit) by means of his resurrection from the dead. The third traditional formula is the hymn of Philippians 2:6-11, which situates the origin of Jesus with God and describes the process by which Jesus assumed the human condition to the point of an unjust death then to be glorified by means of the resurrection. Last in this catalogue of basic traditions one should include the confession of Galatians 4:4-5, centered as it is on the incarnation of the Son.

These traditions contain a series of basic affirmations concerning Jesus:

- his birth, by means of which he became part of the Judean nation

- his death, announced in the Scriptures

- his resurrection, also announced in the Scriptures, by which his true identity as Son of God was revealed

- his exaltation, by which all creation has been made subject to him.

The image of Jesus which appears in the letters of Paul is built on this traditional substratum, in some cases by incorporating further traditions and in others by developing the implications of what here is already affirmed.

What Paul says about the earthly Jesus derives by and large from the tradition. From it, in the first place, come the sayings of Jesus. Although there are only four of Jesus' sayings explicitly cited in the letters (1 Th 4:15; 1 Cor 7:10; 9:14; 11:23-25), allusions and/or reformulations of several others have been routinely identified (Walter 1989:54-57; Hollander 2000; Bedard 2006). By comparison 
with the citations and allusions to the Scriptures, though, the number is limited, but it is important nonetheless to recall that the tradition of the sayings of Jesus had not yet acquired as fixed a form as it would take on in the subsequent generation, when the evangelists incorporated it into their respective writings (Kuhn 1970; Holtz 1991). The quotations, allusions and reformulations of the sayings of Jesus indicate that Paul was acquainted with his teaching, although he did not rely on it in a systematic way to ground his own ethical and paraenetic exhortation.

Beyond the sayings of Jesus, the Pauline letters also reveal some knowledge of other aspects of Jesus' ministry. In Romans 14:17, for example, Paul refers to the kingdom of God with these words:

For the kingdom of God does not consist in that which is eaten or in that which is drunk, but in justice, in the peace and the joy of the Holy Spirit.

This affirmation presupposes some knowledge of the central element of Jesus' preaching (the coming of the kingdom of God), as well as the certainty that it had already been made present by means of the Spirit and its gifts. The correlation of that which is eaten and drunk - or with whom it is eaten or drunk - with the arrival of the kingdom is a mark of Jesus' discourse as it is of Paul's here and elsewhere (Mk 2:15-17; 7:15; Gl 2:14-15), as is the association of the coming of the kingdom of God with the action of the Spirit as well (Mt 12:28; 1 Cor 4:20). In other words, Romans 14:17 reveals clear knowledge of the preaching of Jesus (Dunn 1998:189-195).

That Paul also knew the prayer of Jesus is suggested by his use of the invocation $A b b a$ with which Jesus likewise addressed the Father ( $\mathrm{Rm}$ 8:15-17 and Gl 4:6-7). The fact that he has preserved the Aramaic term presumably used by Jesus himself is a clear indication that even the communities of de Diaspora knew about his particular way of addressing the God of Israel and also that they used this expression in their own prayers.

Lastly, several of Paul's exhortations to imitate the example of Jesus presuppose an acquaintance with the tradition about his lifestyle. In Romans 13:14, for instance, Paul invites his addressees to 'put on the Lord Jesus Christ' and in Romans 15:1-5 he offers several different directions for living a life 'in accordance with Christ Jesus' (Thompson 1991:149-160). Elsewhere Paul describes himself as an 'imitator of Christ' (1 Cor 11:1) and exhorts others to 'have among yourselves the same mind of Christ' (Phlp 2:5). All of these invitations presuppose knowledge of what in the ancient world defined the person most profoundly, that is, his moral character.

The quotations and allusions to the sayings of Jesus, the references to his preaching, to his prayer and to the example of his life, attest more extensive knowledge about the earthly Jesus than might appear in the letters at first glance. The way in which these traditions are remembered and transmitted, moreover, indicates that both Paul and his addressees knew the traditions in flexible form. So, to recall the question with which we began, the most significant feature of the Pauline image of the earthly Jesus is that it is built completely on the basis of traditional elements.

This is all the more significant because it contrasts so sharply with the rich development which can be observed in the image of the risen Jesus. Such has its root in two basic affirmations - the resurrection and the exaltation - upon which Paul builds an elaborate Christology concerning the condition of the resurrected Jesus, as Lord, Son of God, last Adam, et cetera, concerning his preexistence and divine condition and concerning his second coming. Not only does this image of the risen Christ occupy a much wider place in the letters of Paul than the information regarding the earthly Jesus, it is also the result of an original development of the received tradition. ${ }^{1}$

For this reason we can formulate an initial conclusion, which will also serve to sharpen our subsequent inquiry. The image of Jesus which appears in the Pauline letters has its origin in the traditional confessions of faith received by the apostle, but there are important differences in the development of the fundamental affirmations contained in these confessions and in the importance they have in his letters. Those which refer to the earthly Jesus (his incarnation and his death) have been developed on the basis of traditional elements; their place remains rather restrained. By contrast, those which refer to the risen Christ (his resurrection and his exaltation) have been elaborately developed; they include a reflection concerning Jesus' salvific effect and his importance for the believer and they occupy a more considerable place in the letters. In other words, there are in the letters two developments of the image of Jesus to which different weight is given.

\section{The Jesus of Paul}

Until this point we have been concerned with data in the letters of Paul, but the question remains: Did Paul include all that he and his addressees knew about Jesus in his letters? Scholars have responded to this question in various ways, but the majority has found sufficient indication to suggest that one or the other knew more than what is explicitly allowed in the letters.

The first indication that this might be the case is in fact the nature of the letters themselves and the place which they occupy within the relationship of Paul and his addressees. The letters are occasional documents; most of them were written to respond to concrete situations and problems which arose at an advanced stage of the relationship between Paul and the communities which he had founded. Generally speaking, it could be said that the letters of Paul belong to a much broader conversation, with which later readers are not familiar. This means that they presuppose much that we simply cannot know.

As Mauro Pesce (1994:9-34) has rightly noticed, the Pauline letters actually belong to a second phase of the Pauline

1.As a result, in the theologies of Paul considerably more space is dedicated to this aspect; compare, for instance, Dunn (1998:186-206) (on the earthly Jesus) with pp. 207-315 (on the risen Christ). 
preaching. The first, more centered on the announcement of the kerygma, would have occurred in the moment in which Paul and his co-workers established the communities to which the letters were later directed, whilst the second, associated more with Paul's paraenetical exhortation, would correspond to the moment of growth and maturation of the communities, a moment which will have occurred subsequently. The letters are a reflection of this second phase, in which exchange between the apostle and his communities was of various types and for this reason they do not contain systematic instruction of the sort which the first phase would necessarily have included.

It is reasonable, then, to suppose that Paul and his addressees knew more concerning Jesus than that which the letters let on. This supposition is consistent with what we know of the life of Paul, whose knowledge of Jesus goes back at least to the time when, as a zealous Pharisee, he dedicated himself to the persecution of the church. Still, it was only after his conversion that he acquired a more precise and profound knowledge of Jesus, above all during his stay in the communities of Damascus and Antioch. During this period, he visited Jerusalem and met with Peter for as many as fifteen days. This encounter, in particular, to which Paul himself gives considerable importance in the brief account of his personal career (Gl 1:18), more likely than not was intended to corroborate with him what Paul himself had heard about Jesus (Hengel and Schwemer 1997; Dunn 1985; Bockmuehl 2007).

Now, in addition to the sort of knowledge which he would have been able to acquire by listening to others, Paul claims at several points in his letters a direct knowledge by means of various ecstatic experiences of a revelatory nature which seem to have played an important role in his life. In the letter to the Galatians, for instance, he describes the moment of his conversion as a vocational experience, similar to that of the prophet Jeremiah or to that of the Servant of Yahweh (Jr 1,4-10; Is 49,1), in which God was pleased to reveal his Son

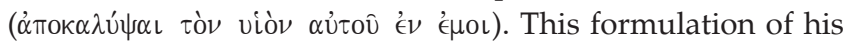
experience as a 'revelation of the Son' is probably the end result of a process which began with the manifestation of the

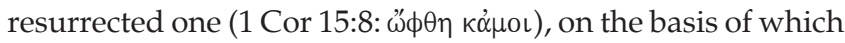
Paul claimed his apostleship, for he also had seen the Lord (1

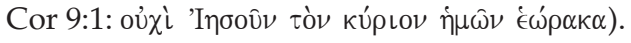

What becomes apparent in terms of Paul's knowledge of Jesus is a process of development. Paul's knowledge grew steadily by means of what he heard about Jesus as a Pharisee, what he learned about him in Damascus and Antioch from the disciples and what he learned from his conversation with Peter in Jerusalem. Above all, however, Paul's awareness of Jesus went from an external knowledge mediated by the testimony of others to a knowledge internal and direct, located in the context of ecstatic experiences of revelation, which seem not to have happened infrequently to him (2 Cor 12:1-5). Paul himself describes this process with a rather enigmatic statement that seems also to include other believers: '... even though we once knew Jesus according to the flesh, we know him like this no longer' (2 Cor 5:16) (Porter 1928; Wolff 1989).

These reflections concerning Paul's knowledge of Jesus allow us to formulate a second conclusion. The disproportion which we encounter in the letters between the memory of the earthly Jesus and the vision of the risen Lord does not result only from their occasional nature, nor simply from the fact that Paul's addressees must have already known the kerygma. The particular intention to reveal the ministry of Jesus manifest especially in his death and resurrection is more adequately explained if we allow in the apostle a process akin to that which he himself describes in 2 Corinthians $5: 16$, a process triggered by the need to know Jesus Christ in a new way. In this manner, regarding Paul's interests, the search for the risen Christ came to displace the earthly Jesus, though the memory of the latter continued nonetheless to be the foundation of Paul's faith and preaching. What still needs clarification, however, is whether the process reflected in Paul's letters was motivated only by an inner experience or whether perhaps contextual factors might also have played a role and it is at this point that the social sciences lend us invaluable service.

\section{The social context in which Paul came to know Jesus}

Traditional studies on Paul have been dominated by a typically Lutheran interest which has privileged theological themes, such as faith, sin and justification, amongst others. Nonetheless, in recent years James Dunn's proposal baptised by Dunn himself as 'a new perspective on Paul' (Dunn 1983; 2007:1-96; Kim 2002), has created new space in the discourse. This new perspective attempts to surface those historical elements which situate the Pauline thought within a context characterised by a pluralistic Judaism and by the various relations of Judeans and Gentiles. The development of Paul's knowledge of Jesus can also be illuminated with the help of this contextual approach, given that such will include factors which facilitated it and in certain ways even propelled it in a precise direction (Neyrey 1990; Malina \& Neyrey 1996).

In order to identify and describe the context in which this development took place it is necessary to distinguish within the first generation between those groups of disciples which emerged in the Syro-Palestinian region (which was the place of origin of the Jesus movement) and the communities established in the cities of the Empire which constituted the Christian Diaspora. Both the country of origin and the Diaspora were part of the Roman Empire, to be sure, but the presence and the influence of the traditional religion of Israel and of the diverse Israelite groups were very different in these two contexts. In the place of origin, at any rate, the various Judean groups were more strongly established such that they exerted an influence which was more determinative than it could ever be in the Diaspora.

The sociology of religion has developed a typology which helps us to understand better the distinction between these two situations and makes possible a more precise description 
of the groups that lived in each. In their beginnings, new religious movements tend to adopt one of the following two forms: In some cases, they emerge as movements of revitalisation which split from other religious groups. In other cases they begin as new movements, whether because they have not arisen from another religious group or because the group from which they derive lacks a significant presence in the new context.

Sociologists call the first groups 'sects' and the second 'cults'. A sect can be defined as a separatist (or schismatic) revitalisation movement which arises out of an established, religiously defined cultural system, with which it shares a symbolic worldview. By contrast, a cult is:

an integrative, often syncretistic, (re)vitalization movement which is effectively imported (by mutation or mobilization) into another religiously defined cultural system, to which it seeks to synthesize a basically foreign (or novel) symbolic worldview.

(White 1988:17; Stark \& Bainbridge 1979, 1996:121-193)

The groups of disciples of Jesus that arose in the SyroPalestinian region fit nicely the typology of the sect: these broke away from another religious group, whose vision of the world they nonetheless shared, but these groups also proposed a profound renovation of that vision on the basis of their commitment to Jesus. The emergence of a diversity of sects is a phenomenon characteristic of Second Temple Judaism, as Albert Baumgarten (1997) has shown and it is in this context that the emergence of the first groups of Jesus' disciples in the Syro-Palestinian region should be located. The main goal of such a movement which has separated from another with the intention of proposing a new and often more radical worldview is to define and affirm its own identity in the face of its group of origin. For this reason, sects develop strategies of separation to distinguish their members from those who belong to the majority religion.

On the other hand, the groups of disciples which first emerged in the Diaspora had the typical characteristics of a cult. The religious group from which they broke away was not the dominant one in their environment. In fact, the religious landscape in the cities of the Empire was characteristically multiform, for alongside the traditional religions of each region, which continued to be practiced, there were various foreign cults, relatively recently introduced, as well as the cult of the emperor, which itself was developing increased importance at the time. In this context, the aim of the Christian communities was not differentiation from other Judean groups, but rather assimilation to their new milieu.

Both sects and cults are characteristically innovative. For this reason, they exist in tension with their social and religious environments and often experience certain difficulties surviving within it. But their individual situations are actually quite distinct and so likewise are their strategies of survival. Sects run the risk of being absorbed by the majority group and because of this tend to highlight their differences in order to survive. By contrast, cults, being strangers within their contexts, face the danger of being rejected and, as a result, they develop strategies of assimilation to their environment.
This distinction is relevant for understanding the differences that existed amongst the various groups of disciples of the first generation and the strategies which they chose with respect to the tradition concerning Jesus. Those located in the Syro-Palestinian region (whose major preoccupation was to distinguish themselves from the dominant form of Israelite religion) were interested in preserving and transmitting the traditions about the earthly Jesus, especially the sayings and anecdotes in which Jesus appeared as a teacher announcing a new interpretation of the Israelite religion. Their need to preserve the memory of Jesus as an element of differentiation goes some way to explaining why the tradition concerning him was preserved here as nowhere else.

The circumstances of the groups of disciples in the Diaspora were considerably different. Their most important concern was to find a place in an environment of religious plurality and, as a consequence, their strategy was assimilation. If they wanted their message to be relevant to those around them, they would have had to present it in terms of the religions with which the latter were familiar. Despite their differences, these neighbouring religions shared a conception of divinity less rigid than that of the strict Israelite monotheism. Heroes and emperors were easily divinised and foreign divinities associated with the mystery cults were eagerly embraced. In any case, the frontiers between the human and the divine were more permeable here than they were within the Israelite conception of God. This context facilitated the development of those elements in the primitive faith in Jesus associated with the risen Christ which Paul had received during the period of his initiation. For this reason, we encounter in his letters a series of innovations in the worship of Christ which seem very much akin to certain elements of the established religions of the imperial world.

Larry Hurtado (2003), in his magnificent study about devotion to Jesus in earliest Christianity, finds explanation for the many honorific titles concerned with Jesus' divine condition in the Pauline communities' practice of worship. In examining the various expressions of worship, he analyses successively: prayer, the invocation and confession of Jesus, baptism in the name of Jesus, the Lord's supper, hymns and prophecy; he observes repeatedly that whilst the form in which the Pauline communities worshipped Jesus was without parallel amongst the other Judean groups of the time, it was very much akin to the communal practices of other religious groups of the imperial environment (Hurtado 2003:137-151). This observation confirms that the Pauline communities tried to assimilate to their milieu, worshipping Jesus in a way which could be recognised as such in the Hellenistic world.

Nonetheless, the recognition of the divine identity of Jesus contains within it a peculiar feature not attested in other religious groups of the imperial environment. This peculiarity arises from the previous affirmation of Israelite monotheism which confessed the existence of a single God. Because of this, in the various expressions of worship as also in the various confessions of faith, recognition of Jesus' 
divinity is closely related to the confession of faith in the one God, to the extent that the same honorific titles are applied to Jesus as to the Father, and the same worship is offered both giving rise to what Larry Hurtado has called a 'binitarian faith' (Hurtado 2003:151-153).

We may then conclude that the apparent disproportion in the Pauline letters between the memory of the earthly Jesus and the image of the risen Lord does not result solely from the nature of the letters or from the nature of the communication between Paul and his communities; rather it reflects in certain ways a process of development which both Paul and his communities would have experienced. The previous discussion concerning the context in which the significance and identity of Jesus was progressively elaborated suggests that this context was determinative for the understanding and development of the primitive confessions of faith which Paul would have received. The need which the new cult experienced to find a place in the religious world of the Empire contributed, no doubt, to the fact that the primitive Christian faith, which confessed the resurrection and exaltation of Jesus, also developed a worship practice and a theology which presupposed the plain recognition of his divinity.

Still, this contextual consideration is not sufficient on its own to explain the early acknowledgement of the divinity of Jesus within the current of a strongly monotheistic tradition. For this decisive step, another factor was determinative.

\section{The life context in which Paul came to know Jesus}

In discussing the process by which Paul came to know Jesus, we have mentioned the tradition which he received during his time in Damascus and Antioch, as well as his conversation with Peter in Jerusalem, which may have continued in Antioch (Gl 2:11-14). But we have also alluded to another and rather different form of knowledge which Paul mentions in his letters: the manifestation of the resurrected one (whom he claims to have seen) and God's own revelation of His Son to him. Western mentality finds itself uncomfortable before these statements, but Paul and his addressees alike granted these revelatory experiences extraordinary weight. If we intend to understand the development of Paul's vision of Jesus, we must consider what these experiences meant and what role they played in the process of its development.

In his letters Paul speaks occasionally of individual experiences - his own visions and revelations - such as those described in 2 Corinthians 12:1-5. More often, however, he speaks of communal experiences, those which the assemblies in Corinth experienced, for instance, in which some prophesied, others spoke in tongues and still others received revelations. However, when Paul mentions these in 1 Corinthians 14 he is not referring to an extraordinary gathering of the community, but rather to the ordinary assemblies. Such is the manifestation of the Spirit, which enlivens the presence of Christ in the midst of the community and in the innermost being of the believer (Dunn 1975).

Nonetheless, what deserves to be underlined here is not the fact that in the Pauline communities the sort of religious and charismatic experiences attributed to the action of the Spirit seem to have been unexceptional, but rather the role that these experiences played in the process by which Paul and his addressees came to a deeper comprehension of the identity of Jesus. The most decisive step in this process, manifest with particular clarity in their expression of worship, was the recognition of Jesus' divine condition for it was due to this recognition that Jesus was confessed and worshipped together with the God of Israel, modifying in this way the rigid expression of Israelite monotheism.

This religious innovation had enormous significance, and in fact it is difficult to find anything comparable in contemporary Judaism. For the Israelite (who recited three times a day the shema) saying 'Hear O Israel, the Lord our God is one' (Dt 6:4), confessing and worshiping Jesus as someone 'equal to God' (Phlp 2:6) was simply inconceivable. Yet despite this, many Israelites like Paul, zealous and observant of the law, took this step. Now a change such as this, which affected the most profound convictions of faith, would likely only have been possible under the condition of some form of supernatural legitimisation and it is here, precisely, that the revelatory experiences of which Paul speaks when referring to his own experience (1 Cor 9:1; 15:8; Gl 1:15-16; 2 Cor 12:1-5), played the decisive role.

Sociologists who study religious phenomena have long suggested a tight relationship between religious experience and innovation. In most cases, the religious experiences which stand at the origin of a new religion or a movement of renovation are experiences of a revelatory character, in which either God is made manifest or the divine will is made known. In either case, these revelatory experiences carry enormous legitimatory weight - they are, after all, the direct manifestation of God - which serves to justify and sustain the new religion or the new movement. These are precisely the sort of encounters to which Paul refers in relating his own experience and it seems reasonable to conclude that they will have served similarly in the process by which he and his communities discovered the divinity of Jesus and dared to worship him alongside the God of Israel (Stark 1965: 107-111; Hurtado 2000).

This observation complements what we have already observed and allows us to identify another factor which influenced the process by which Paul and his addressees discovered the importance of the traditional affirmations concerning the resurrection and the exaltation of Jesus. The disproportion which we have found in the Pauline letters between the memory of the earthly Jesus and the constant reference to the risen Lord reflects a process in which Paul and his communities discovered the identity of Jesus progressively, each time with more clarity. In this process, 
two factors intervened in such a way as to facilitate and even to encourage this discovery. The first of these, as we have already indicated above, was the peculiar situation of the groups of disciples in the Diaspora and, in particular, their need to find a place within a religious context which maintained a concept of the divine very different from that of the Israelite religion. The second was a series of revelatory experiences which served to legitimate the recognition of the divinity of Jesus and to underwrite a style of worship in which he was revered alongside of God. This recognition and this worship implied a profound reformulation of Israelite monotheism, which in Pauline circles took the form of a binitarian faith.

This new conviction, legitimated as it was by revelatory experiences, led Paul and his communities to revise their initial vision of Jesus. At any rate, this is likely what lies behind the affirmation of 2 Corinthians 5:16. Paul had known the traditions about Jesus - he had even encountered eye witnesses like Peter - but urged on by the new situation which his communities were experiencing and provoked by his own intense experiences and those of others, he had come to know Jesus in a new way - he had entered into the mystery of his person, in other words, and discovered whom he was in reality. The earthly Jesus, whose memory remained nonetheless present, was only part of this mystery which was revealed to Paul gradually.

\section{Conclusion}

This short article has attempted to explore the way in which attention to contextual factors might help to better understand the disproportioned development of some aspects of the early tradition about Jesus in the Pauline correspondence. A purely conceptual approach to the problem implied in the vision of Jesus which Paul presents in his letters runs the risk of forgetting the circumstances and lived reality in which this vision was progressively articulated, neglecting the fundamental point that Paul, like all believers, experienced a development in his awareness of Jesus.

In this study we have suggested two factors which likely influenced this process. The first has to do with the circumstances of Paul's communities; in other words, with the way in which these small communities of the Diaspora were forced to find a place for themselves in the world only with great effort. The second reminds us of the fundamental role which religious experience played in the process by which Paul's vision of Jesus was transformed. These factors take nothing away from the greatness of Paul's theology; quite the contrary, they bring it closer to the experience of all believers, who might find in that early experience an exemplary path of faith.

\section{References}

Barbaglio, G., 2006, Gesù di Nazaret e Paolo di Tarso: Un confronto storico, Edizion Dehoniane, Bologna.

Baumgarten, A.I., 1997, The flourishing of Jewish sects in the Maccabean era, Brill, Leiden.

Bedard, S.J., 2006, 'Paul and the historical Jesus: A case study in First Corinthians', McMaster Journal of Theology and Ministry 7, 9-22.

Blank, J., 1968, Paulus und Jesus. Eine theologische Grundlegung, Kösel-Verlag, München.

Bockmuehl, M., 2007, 'Peter between Jesus and Paul: The "Third Quest" and the "New Perspective" on the first disciple', in T.D. Still (ed.), Jesus and Paul reconnected: Fresh pathways into an old debate, pp. 67-102, Eerdmans, Grand Rapids.

Dunn, J.D.G., 1975, Jesus and the Spirit: A study of the religious and charismatic experience of Jesus and the first Christians as reflected in the New Testament SCM, London.

Dunn, J.D.G., 1983, 'The new perspective on Paul', Bulletin of the John Rylands Library 65, 95-122.

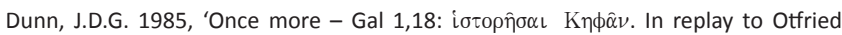
Hofius', Zeitschrift für die neutestamentliche Wissenschaft 76, 138-139.

Dunn, J.D.G., 1998, The theology of Paul the apostle, London 1998

Dunn, J.D.G., 2007, The new perspective on Paul, Eerdmans, Grand Rapids.

Häusser, D., 2006, Christusbekenntnis und Jesusüberlieferung bei Paulus, Moh Siebeck, Tübingen.

Hengel, M. \& Schwemer A.M., 1997, Paul, between Damascus and Antioch: The unknown years, SCM, London.

Hollander, H.W., 2000, 'The words of Jesus: From oral traditions to written record in Paul and Q', Novum Testamentum 42, 340-357.

Holtz, T., 1991, 'Paul and the oral gospel tradition', in H. Wansbrough (ed.), Jesus and the oral gospel tradition, pp. 380-393, Academic Press, Sheffield.

Hurtado, L.W., 2000, 'Religious experience and religious innovation in the New Testament', The Journal of Religion 80, 183-205.

Hurtado, L.W., 2003, Lord Jesus Christ: Devotion to Jesus in earliest Christianity, Eerdmans, Grand Rapids.

Kim, S., 2002, Paul and the new perspective, Mohr Siebeck, Tübingen.

Kuhn, H.-W., 1970, 'Der irdische Jesus bei Paulus als traditionsgeschichliches und theologisches Problem', Zeitschrift für die Theologie und Kirche 67, 295-320.

Malina, B.J. \& Neyrey, J.H., 1996, Portraits of Paul: An archaeology of ancient personality, Westminster/John Knox, Louisville.

Neyrey, J.H., 1990, Paul in other words: A cultural reading of his letters, Westminster/ John Knox, Louisville.

Pesce, M., 1994, Le due fasi della predicazione di Paolo. Dall'evangelizzazione alla guida della comunità, Edizioni Dehoniane, Bologna.

Porter, F.C., 1928, 'Does Paul claim to have known the historical Jesus? A study of 2 Corinthians 5:16', Journal of Biblical Literature 47, 257-275.

Stark, R., 1965, 'A taxonomy of religious experience', Journal for the Scientific Study of Religion 5, 97-116.

Stark, R. \& Bainbridge, W.S., 1979, 'Of churches, sects, and cults: Preliminary concepts for a theory of religious movements', Journal for the Scientific Study of Religion $18,117-131$.

Stark, R. \& Bainbridge, W.S., 1996, A theory of religion, 2nd edn., Rutgers University Press, New Brumswick.

Thompson, M., 1991, Clothed with Christ: The example and teaching of Jesus in Romans 12,1-15,13, Academic Press, Sheffield.

Walter, N., 1989, 'Paul and the early Christian Jesus-tradition', in A.J.M. Wedderburn (ed.), Paul and Jesus, pp. 51-80, Academic Press, Sheffield.

Wedderburn, A.J.M., 1989, 'Paul and Jesus: The problem of continuity', in A.J.M Wedderburn (ed.), Paul and Jesus: Collected essays, pp. 99-115, Academic Press, Sheffield.

Wenham, D., 1995 Paul, follower of Jesus or founder of Christianity?, Eerdmans, Grand Rapids.

White, L. M., 1988, 'Shifting sectarian boundaries in early Christianity', Bulletin of the John Rylands Library 70, 7-24.

Wolff, C., 1989, 'True apostolic knowledge of Christ: Exegetical reflections on 2 Corinthians 5.14ff.', in A.J.M. Wedderburn (ed.), Paul and Jesus: Collected essays, pp. 81-98, Academic Press, Sheffield. 